\title{
Nesting biology and phenology of a population of Halictus farinosus Smith (Hymenoptera, Halictidae) in northern Utah
}

\author{
Jennifer Robin Albert' ${ }^{\prime}$ Laurence Packer ${ }^{1}$ \\ I Department of Biology, York University, 4700 Keele Street, Toronto, Ontario, Canada \\ Corresponding author: Jennifer Robin Albert (Jalbert@yorku.ca)
}

Academic editor: J. Neff| Received 8 January 2013 | Accepted 15 March 2013 | Published 24 April 2013

Citation: Albert JR, Packer L (2013) Nesting biology and phenology of a population of Halictus farinosus Smith (Hymenoptera, Halictidae) in northern Utah. Journal of Hymenoptera Research 32: 55-73. doi: 10.3897/JHR.32.4646

\begin{abstract}
Nesting biology and phenology in an aggregation of the primitively eusocial ground-nesting bee Halictus farinosus were studied at Green Canyon, Utah from May to August, 2010. Nest architecture was typical of the genus. Nests were small with an average of 3.5 worker and 13.5 reproductive brood per colony. Most workers were mated (77.5\%) and had ovarian development (73.4\%). The queen-worker size differential was moderate $(8.8 \%$ for head width and $6.2 \%$ for wing length), indicating that sociality in this species is of intermediate strength compared to other social Halictus species. Results from 2010 were compared with those from 1977/1978 and 2002. Varying weather patterns in the years of study led to changes in phenological milestones: in the colder and wetter spring of 2010, nesting behavior was delayed by up to two weeks compared to the other years. While nest productivity was comparable among years, in 2010 the size difference between queens and workers was significantly larger than in 2002, indicating an effect of annual variation in weather conditions on social parameters in this species.
\end{abstract}

\section{Keywords}

Sweat bee, phenology, nesting biology, natural history, nest architecture, primitive eusociality, social variability, degree days 


\section{Introduction}

The development of eusociality from solitary ancestors is considered one of the major transitions in evolution (Maynard Smith and Szathmary 1995). In order to understand how this transition took place, it is necessary to study organisms exhibiting primitive or weak eusociality, as is found in the subfamily Halictinae (Packer 1986; Packer 1992; Richards and Packer 1995; Mueller 1996; Richards 2001; Soucy 2002; Richards et al. 2010; and see Schwarz et al. 2007). Indeed, primitively eusocial halictines share many similarities with the predicted ancestors of the highly eusocial corbiculate apids (Cardinal and Danforth 2011). Their potentially pivotal role in aiding out understanding of the evolution of eusociality requires the comparison of critical sociobiological parameters among populations both within and between species. The most frequently studied variables include the number of workers and reproductives produced per colony, the sex ratio in the worker and reproductive brood, queen-worker size differential, queen-worker ovarian development differences and the proportion of workers that mate (Packer 1986; Packer 1992; Richards et al. 2010).

The size of an adult bee depends on the quality (Roulston and Cane 2002) and size (Plateaux-Quénu 1983; Richards and Packer 1994) of the food mass provided for it. In ground nesting bees the size of the food mass and the number that can be produced will depend on multiple environmental and biological factors including the size and activity levels of active foragers in the nest (Gathmann and Tscharntke 2002; Pereboom and Biesmeijer 2003) and the amount of available resources which, in turn, are highly dependent on weather and other environmental factors (Packer 1990; Minckley et al. 1994; Richards and Packer 1996; Richards 2004). Repeat field studies of the same population can allow us to make comparisons between years to determine how weather patterns might affect phenology, productivity and sociobiology. This will also help us to better predict how pollinators might respond to changing ecological conditions (Richards and Packer 1995; Bartomeus et al. 2011).

Halictus farinosus Smith is found in western North America ranging from British Columbia, south to California and east to Nebraska (Ascher and Pickering 2011). It is polylectic and has been reported foraging on 43 plant species from 14 different families (Nye 1980) and is thought to be an important pollinator of carrot (Nye 1980), onion (Parker 1982), and sunflower (Parker 1981). In Utah, H. farinosus nests in dry, sandy soil in areas of sparse vegetation. Its nests are usually unbranched and are up to $65 \mathrm{~cm}$ deep (Nye 1980; Sellars 2004).

Halictus farinosus has a two-phase life cycle and exhibits colony social organization similar to other primitively eusocial halictines (reviewed by Schwarz et al. 2007; Richards et al. 2010). In northern Utah, queens found nests independently from April to May (Nye 1980; Sellars 2004), and produce a first worker brood. In turn the workers help to produce a second, reproductive brood (gynes and males) which begins to emerge in mid August. The species has also been studied in California (Eickwort 1985) where its biology is similar except that the nests extend up to $80 \mathrm{~cm}$ in depth and a 
larger worker brood is produced (Eickwort 1985). The nesting season is also longer in California, lasting from mid February to October (Eickwort 1985).

In this study we present phenological, sociobiological and nest architecture data from field studies on Halictus farinosus in North Logan, Utah. As this population has been studied previously (Nye 1980; Sellars 2004) we compare phenological and nest productivity data among years of study. We also make comparisons between $H$. farinosus and other closely related Halictus species.

\section{Methods}

\section{Study sites and nest excavations}

Nests were excavated in July and August 2010 at Green Canyon, North Logan, Utah (N41\%46.15, W111 46.39 , elevation $1590 \mathrm{~m}$ ) where $H$. farinosus had been previously studied (Nye 1980; Sellars 2004). The site was a $0.25 \mathrm{~km}^{2}$ field near the mouth of the canyon. Six $2 \times 2 \mathrm{~m}$ study sites with high levels of $H$. farinosus nesting activity were sectioned off and marked B to G. These sites were further divided into quadrats of 1 $\mathrm{m}^{2}$ each. Sites varied in nest density from ten to over fourty nests per site in early June. The majority of nests excavated came from these sites and those that were from outside of these quadrats were given a code beginning with N. Each site was monitored every second day for at least two hours during daylight from 13 June until 30 July and on 5 and 6 August excepting days with exceptionally bad weather (ie. heavy rain throughout most of the day). Monitoring consisted of observing and recording nests at each site for any activity around nest entrances, including: foundresses or workers leaving or returning to the nest, conspecific interactions near the nest entrance, predation of $H$. farinosus in the nest area and the entry of natural enemies into the nest. Nest mortality was calculated by comparing the number of nests with activity in the first round of monitoring, while foundresses are foraging to produce the first brood (mid-June), compared to those active in the last round during the worker foraging period just before the reproductives were ready to emerge (August $5^{\text {th }}$ and $6^{\text {th }}$ ). Before the emergence of workers, foundresses from sites $\mathrm{C}$-H were marked with unique 3-colour combinations of Testors ${ }^{\mathrm{TM}}$ enamel paint on their thoracic dorsum so they could be identified later in the season. Marked foundresses were confirmed and unmarked queens were identified as the mother of the worker offspring by genotyping at six microsatellite loci (see Albert 2012).

Nests referred to as first brood nests are those excavated on or before 17 July which was the date when the first workers emerged. Second brood nests were any nests excavated after 17 July. Most second brood nests, referred to as late summer nests, were excavated during a short period in the week following 7 August, just before the second brood began to emerge (see Table S1 for excavation dates). This was done to maximize the amount of the second brood that was present during excavation. 
Table I. Summary of phenological data for all $H$. farinosus studies in Green Canyon. N/A indicates that the information in the column was not given in the study. In Sellars (2004) female and male reproductive emergence dates were not differentiated so the same date was given for each.

\begin{tabular}{c|c|c|c|c}
\hline & $\mathbf{1 9 7 6}$ & $\mathbf{1 9 7 7}$ & $\mathbf{2 0 0 2}$ & $\mathbf{2 0 1 0}$ \\
\hline Queen foraging slows & N/A & N/A & 28 June & 12 July \\
\hline First adult worker & "Late June" & 8 July & 2 July & 15 July \\
\hline $\begin{array}{c}\text { First reproductive } \\
\text { brood cells }\end{array}$ & N/A & N/A & 3 July & 17 July \\
\hline $\begin{array}{c}\text { First reproductive } \\
\text { adult male }\end{array}$ & "Late July" & "Early August" & 30 July & 11 August \\
\hline $\begin{array}{c}\text { First reproductive } \\
\text { adult female }\end{array}$ & "Early August" & "Mid August" & 30 July & 12 August \\
\hline Source & Nye, 1980 & Nye, 1980 & Sellars, 2004 & Present study \\
\hline
\end{tabular}

Nest entrances were blocked before dawn on the morning of excavation to ensure that all nest members would be captured during excavation. Nest excavation methods were as described by Packer and Knerer (1986). All nest occupants including juveniles in various developmental stages were collected in ethanol and stored at $-20^{\circ} \mathrm{C}$.

\section{Dissections and measurements}

Adult females were dissected and measured using a Leica WILD M3B light microscope equipped with an ocular micrometer at $16 \mathrm{x}$ magnification following the general methods of Ordway (1965). Wing and mandible wear were each ranked with a score ranging from 0 to 5 where 0 was no wear and 5 was extremely worn. Wear scores, head width and wing length measurements followed the methods of Richards et al. (2010). Ovarian development was assessed based on the size of developing oocytes following Packer (1986): 0 when no oocytes were developed and 1 for each fully developed oocyte. Intermediate conditions were scored to the nearest quarter based on size relative to a complete egg. These data were summed to give an overall development score (see Packer 1986). Adults said here to have "ovarian development" had a score of 0.25 or greater. Matedness was determined by inspection of the spermatheca. Sexing of juvenile brood was accomplished by genotyping at six microsatellite loci (see Albert 2012) and confirmed in pupae by morphological inspection. Sex ratio was calculated in nests where the sexes of the full complement of brood were determined.

Size differences between castes were calculated following Packer (1992) as

$$
D=\frac{\mathrm{S}_{\mathrm{Q}}-\mathrm{S}_{\mathrm{w}}}{\mathrm{S}_{\mathrm{Q}}}
$$

where $S_{Q}$ and $S_{W}$ are the sizes (head width or wing length in $\mathrm{mm}$ ) of the queen and worker respectively. 


\section{Weather}

Weather data were gathered from the Utah State University climate centre website (2011) from a weather station $5.5 \mathrm{~km}$ away from the study site for all years this population had been studied $(1976,1977,2002,2010)$. The 65 year average temperature, used to cover all years of study and the 30 years before the initial year of study, was also obtained from this website. Degree days (base 10) were calculated for each day by the basic equation:

$$
D D=\frac{\mathrm{T}_{\text {min }}-\mathrm{T}_{\text {max }}}{2}-10
$$

Where $\mathrm{T}_{\text {min }}$ and $\mathrm{T}_{\max }$ are the minimum and maximum temperatures reached that day. These data were used to calculate cumulative degree days (Zalom et al. 1983).

\section{Calculations and statistical analyses}

Foundress productivity was measured as the average number of offspring (including all eggs, larvae, pupae and callow adults) in first brood nests after the foundress had stopped foraging. Productivity in second brood nests was calculated as brood per working female. Because worker mortality was high, minimum productivity was also calculated as the number of second brood offspring present divided by the average number of first brood individuals found in nests multiplied by the proportion of first brood that was female. The sex ratio presented is the number of males divided by all brood.

A paired T-test was used to compare the size of the queen with that of her largest worker. Because most parameters measured were not normally distributed, all other tests of significance were Wilcoxon Mann-Whitney rank sum tests performed in R (version 2.15.2, $\mathrm{R}$ core team 2012).

\section{Results}

\section{Phenology}

All colonies studied were singly founded and foraging had commenced in some colonies by the initiation of the study on 13 June 2010. Only one $H$. farinosus female was witnessed to initiate excavation of her nest after this point. The last foraging trip taken by a foundress was observed on 12 July (Table 1). From early July, foundresses were frequently seen guarding nest entrances and rarely left the nest. Nest excavations began on 28 June, the first fully developed adult worker found in a cell was excavated on 15 July and the first adult first brood individual, a female, was observed leaving a nest on 17 July (Table 1). No new nests were founded after first brood emergence in the area of 


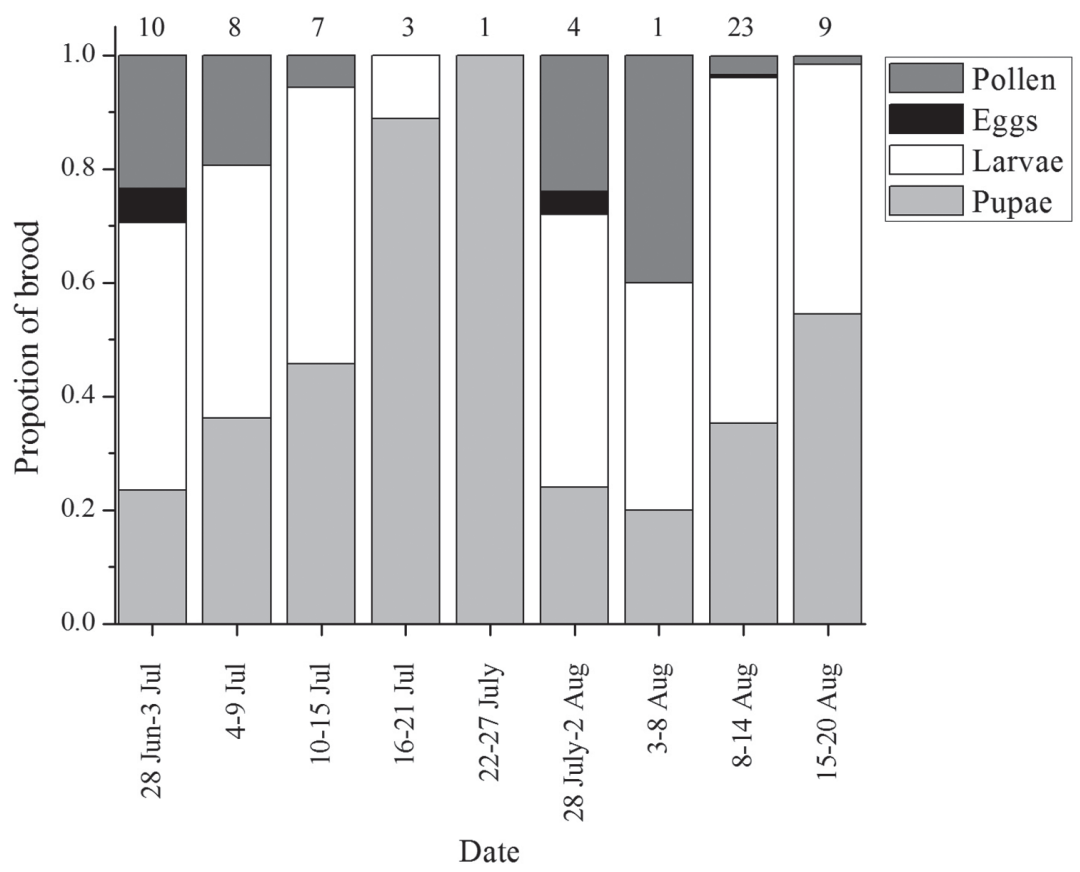

Figure I. Percentage of brood in different developmental stages throughout the season, taken every six days. The rate of nest excavation throughout the season was not consistent. Numbers above each column represents the number of nests excavated during that time period.

observation. Although detailed data were not collected, daily observations at the nest site indicated that worker foraging slowed noticeably after the first week of August. The first fully developed, second brood male was found on 11 August and the first adult female in the second brood was excavated on 12 August. Figure 1 shows nest contents by developmental stage over 6 day periods throughout the season.

Surveys of all study plots conducted in mid-June and repeated in early August indicated a nest mortality rate between these times of $59.5 \%$. Colonies that were particularly inactive may have been missed in either survey.

\section{Nest architecture}

Halictus farinosus nests in Green Canyon were easily identified by their large tumuli (see Nye, 1980). Bees entered the nest through a tunnel that ran horizontally through to the middle of the tumulus to the main burrow which was typically vertical. Two nests had one brood-containing branch off the side of the main tunnel and one had two brood-containing branches (as in Packer and Knerer 1986). All cells were constructed directly off the side of the main tunnel (see Nye 1980) or off of a side branch and measured approximately $1.4 \mathrm{~cm}$ long $(\overline{\mathrm{x}}=1.40, \mathrm{SD}=0.29, \mathrm{~N}=7)$ and $0.7 \mathrm{~cm}$ wide $(\overline{\mathrm{x}}=0.66, \mathrm{SD}=0.14, \mathrm{~N}=7)$ with a slightly constricted neck. 
Nest depth for first brood nests ranged from 11 to $41 \mathrm{~cm}(\bar{x}=20.4 \mathrm{~cm}, S D=7.3$, $\mathrm{N}=29$ ), and shallowest and deepest brood cells were $7 \mathrm{~cm}$ and $20 \mathrm{~cm}$ respectively ( $\overline{\mathrm{x}}$ $=14.4 \mathrm{~cm}, \mathrm{SD}=2.8, \mathrm{~N}=29$ ). Second brood nests ranged from $12 \mathrm{~cm}$ to $44.5 \mathrm{~cm}$ in depth $(\overline{\mathrm{x}}=30.3 \mathrm{~cm}, \mathrm{SD}=6.1, \mathrm{~N}=37)$ and as a result were significantly deeper $(\mathrm{W}=$ $153, \mathrm{p}<0.001)$ than first brood nests. Second brood nests had cells reaching to or very near to the end of the burrow.

The average number of cells in first brood nests was $4.4(\mathrm{SD}=2.0, \mathrm{~N}=29)$ including brood cells, empty cells and those containing only pollen. There were significantly more cells in second brood nests with an average of 20.1 in nests excavated late in summer (after 7 August) ( $\mathrm{SD}=10.1, \mathrm{~N}=32, \mathrm{~W}=79, \mathrm{p}<0.0001$ ) which were expected to approach maximum brood sizes. This included empty cells that were previously occupied by first or second brood individuals and cells with mouldy contents. The percentage of cells containing mouldy contents (mostly pollen) over all nests was $6.7 \%$.

In both broods, individuals at later developmental stages tended to be relatively closer to the nest entrance and cells containing only fresh pollen were always among the deepest excavated indicating that shallower cells were completed first.

\section{Spring and summer brood productivity}

Sixty-six nests were excavated, 29 containing juvenile first brood and 37 containing mostly the second, reproductive brood. The first brood nests contained between 0 and 7 first brood individuals with an average of $3.5(\mathrm{SD}=2.0, \mathrm{~N}=29)$. There were fewer brood than brood cells because in some cases cells were unfinished or contained mouldy pollen.

At the time of excavation an average of only 1.7 adult workers (range $0-7$ ) were present within second brood nests. Active second brood nests produced between 1 and 46 brood with an average of 13.5 per nest $(\mathrm{SD}=9.9, \mathrm{~N}=37)$.

A breakdown of all nest contents in the first and second brood nests is presented in Table S1. The nest foundress was present in 22 of 29 first brood nests and 13 of 32 second brood nests (Figure 2). It could not be determined if the foundress was present in the remaining five second brood nests because adults in those nests had not been marked and genotype data were not available. Mean productivity of the foundress alone (first brood nests) was between 0 and 7 with an average of 3.5 brood, comprising 3.0 females and 0.5 males per nest. The sex ratio in the first brood was 0.149 weighting nests equally and 0.159 with individuals weighted equally. Mean productivity of first brood females was calculated using an estimate of the number of first brood females over the lifetime of the colony. As the mean number of second brood individuals produced per nest was 13.5 this gives 4.5 reproductive brood per worker female. Mean maximum second brood productivity per worker using the actual number of workers found in the nest was 7.0. The sex ratio in the second brood was not significantly different from 1:1 at 0.464 averaged over nests and 0.445 in the population as a whole. 


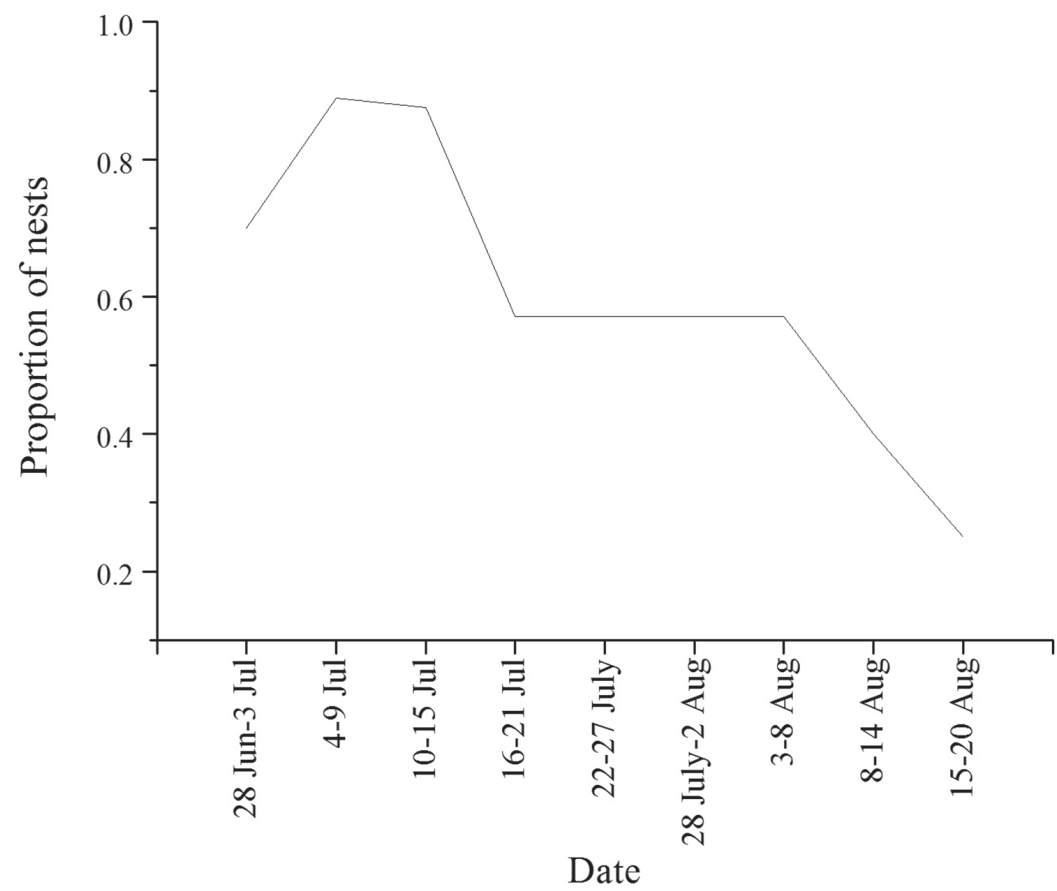

Figure 2. Proportion of nests excavated with the queen present, organized in 6 day intervals. Very few excavations took place between 16 July and 8 August so data are pooled together to show overall trend during this period. See Figure 1 for the number of nests excavated during each period.

\section{Caste dimorphism}

Dissections of 49 workers revealed that $36(73.5 \%)$ had some level of ovarian development and 31 of $40(77.5 \%)$ were mated (the spermatheca was not found in 9 of the workers dissected)(Table 2). All queens dissected were mated $(\mathrm{N}=31)$ and all but one that was found dead in the nest with desiccated ovaries had some level of ovarian development $(\mathrm{N}=31)$. The level of ovarian development in queens $(\overline{\mathrm{x}}=1.185, \mathrm{SD}$ $=0.668, \mathrm{~N}=31$, Table 2$)$ was significantly greater than in workers $(\overline{\mathrm{x}}=0.648, \mathrm{SD}$ $=0.673, \mathrm{~N}=49, \mathrm{~W}=884.5, \mathrm{p}=0.001$, Table 2). Workers in nests where the queen was present had lower but not significantly less ovarian development than workers in orphaned colonies (Table 3).

Queens averaged significantly larger than workers in both head width and wing length (Table 2). This gives a population-wide caste size difference of $6.25 \%$ for head width and $6.37 \%$ for wing length. Queens were also generally larger in both measures than their own workers with a mean percent difference of $8.79 \%$ for head width and $6.19 \%$ for wing length. Queens were found to be significantly larger than their largest worker in a paired T-Test for both head width $(\mathrm{t}=3.34, \mathrm{p}=0.007)$ and wing length $(\mathrm{t}=2.77, \mathrm{p}=0.018)$. 
Table 2. Comparisons of ovarian development, matedness, head width, wing length, mandible and wing wear between queens and workers throughout the 2010 season. Means are presented with their standard deviations.

\begin{tabular}{c|c|c|c}
\hline & Queen & Worker & $\begin{array}{c}\text { Statistical } \\
\text { comparison }\end{array}$ \\
\hline $\begin{array}{c}\text { Amount of ovarian } \\
\text { development }\end{array}$ & $1.185+/-0.668,31$ & $0.648+/-0.673,49$ & $\mathrm{~W}=884.5, \mathrm{p}=0.001$ \\
\hline $\begin{array}{c}\text { Percentage with developed } \\
\text { ovaries }\end{array}$ & $96.8, \mathrm{~N}=31$ & $73.5, \mathrm{~N}=49$ & \\
\hline Percentage mated & $100, \mathrm{~N}=31$ & $77.5, \mathrm{~N}=40$ & \\
\hline Head width $(\mathrm{mm})$ & $3.52+/-0.15, \mathrm{~N}=33$ & $3.30+/-0.15, \mathrm{~N}=55$ & $\mathrm{~W}=1528, \mathrm{p}<0.0001$ \\
\hline Wing length $(\mathrm{mm})$ & $3.14+/-0.15, \mathrm{~N}=27$ & $2.94+/-0.13, \mathrm{~N}=45$ & $\mathrm{~W}=1017, \mathrm{p}<0.0001$ \\
\hline Mandible wear & $3.75+/-1.21, \mathrm{~N}=28$ & $3.57+/-1.53, \mathrm{~N}=45$ & $\mathrm{~W}=749, \mathrm{p}=0.61$ \\
\hline Wing wear & $3.13+/-1.36, \mathrm{~N}=30$ & $2.81+/-1.64, \mathrm{~N}=43$ & $\mathrm{~W}=655, \mathrm{p}=0.232$ \\
\hline
\end{tabular}

Queens were not generally more worn than workers in either mandible or wing wear (Table 2). Both wing and mandible wear increased throughout the season in queens, and more steeply in workers (Figure 3).

\section{Temperature and rainfall}

Minimum and maximum temperatures were low in the spring of 2010 compared to the 65 year average but were comparable to the average throughout the summer (Figure 4). Spring rainfall was high in 2010 compared to average, but was close to average throughout the rest of the season (Figure 5). Degree days accumulated slowly in 2010 compared to the other years of study (Figure 6) due to colder maximum and minimum temperatures in the spring (Figure 4). Degree days in 1976 and 1977 accumulated more quickly than in the more recent years of study (Figure 6) due to high minimum temperatures in these years (Figure 4).

\section{Comparisons between years of study}

Nests were shallower in both brood producing periods in 2010 (Brood 1: $\overline{\mathrm{x}}=22.1, \mathrm{SD}$ $=7.4, \mathrm{~N}=21, \mathrm{~W}=434, \mathrm{p}=0.022, \operatorname{Brood} 2: \overline{\mathrm{x}}=30.3, \mathrm{SD}=6.1, \mathrm{~N}=37, \mathrm{~W}=2694, \mathrm{p}<$ 0.0001) compared to 2002 (Sellars, 2004; Brood 1: $\overline{\mathrm{x}}=26.7, \mathrm{SD}=6.8, \mathrm{~N}=30$, Brood $2: \bar{x}=42.7, S D=10.6, N=86$, Table 3). However, the number of brood produced per nest in both worker and reproductive phases was comparable. The number of first brood individuals produced in $2010(\overline{\mathrm{x}}=3.52, \mathrm{SD}=1.96, \mathrm{~N}=29)$ and $2002(\overline{\mathrm{x}}=3.20$ $\mathrm{SD}=2.64, \mathrm{~N}=30$ ) did not differ significantly ( $\mathrm{W}=488, \mathrm{p}=0.420$, Table 3$)$. Second brood productivity also did not differ significantly $(2010: \overline{\mathrm{x}}=13.49, \mathrm{SD}=9.93, \mathrm{~N}=$ 


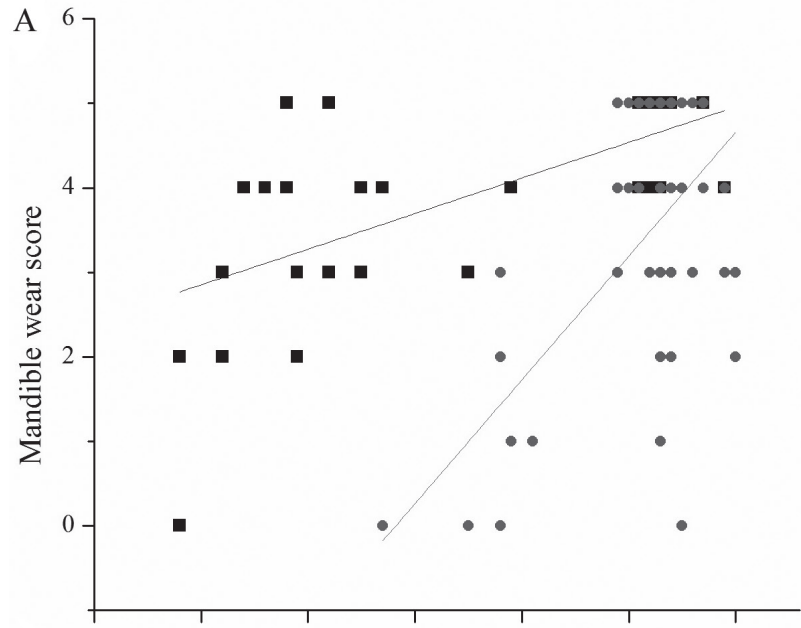

- Wear in queens

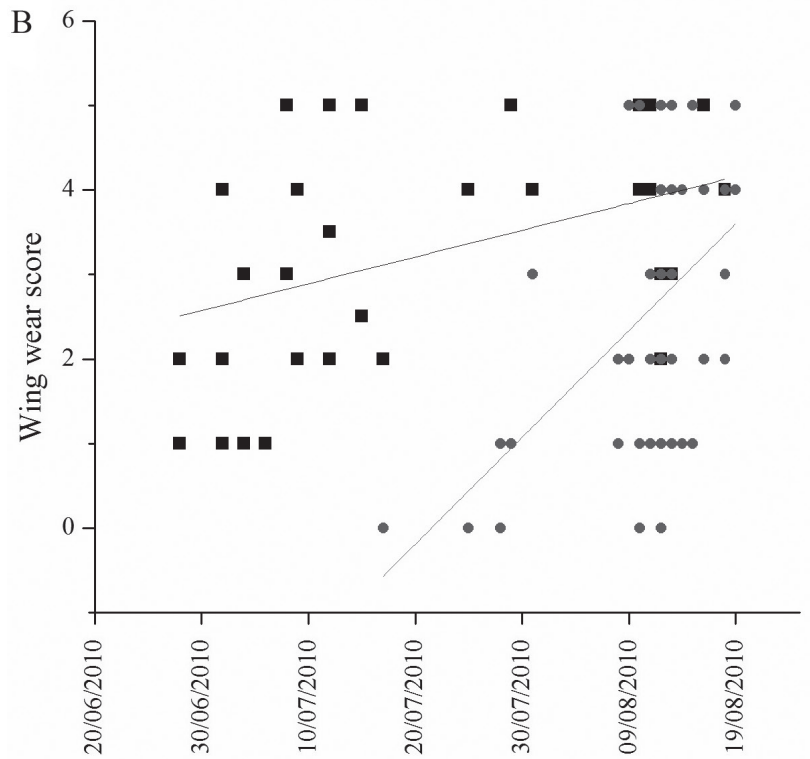

- Wear in workers

Date

Figure 3. Wear of mandibles (a) and wings (b) of queens (black squares) and workers (grey circles) over time.

Table 3. Comparison of $H$. farinosus nest size, number of cells and mean offspring number in 2002 and 2010.

\begin{tabular}{c|c|c|c|c}
\hline & & $\mathbf{2 0 0 2}$ & $\mathbf{2 0 1 0}$ & Statistical comparison \\
\hline \multirow{3}{*}{ First Brood } & Depth $(\mathrm{cm})$ & $26.7+/-6.8$ & $22.1+/-7.4$ & $\mathrm{~W}=434, \mathrm{p}=0.022$ \\
\cline { 2 - 5 } & Cells per nest & $1-12$ & $1-9$ & \\
\cline { 2 - 5 } & Mean offspring $+/-$ SD & $3.2+/-2.64$ & $3.5+/-2.0$ & $\mathrm{~W}=488, \mathrm{p}=0.420$ \\
\hline \multirow{3}{*}{ Second Brood } & Depth $(\mathrm{cm})$ & $42.7+/-10.6$ & $30.3+/-6.1$ & $\mathrm{~W}=2694, \mathrm{p}<0.0001$ \\
\cline { 2 - 5 } & Cells per nest & $3-56$ & $3-45$ & \\
\cline { 2 - 5 } & Mean offspring $+/-$ SD & $13.1+/-13.4$ & $13.5+/-9.9$ & $\mathrm{~W}=1727.5, \mathrm{p}=0.184$ \\
\hline
\end{tabular}



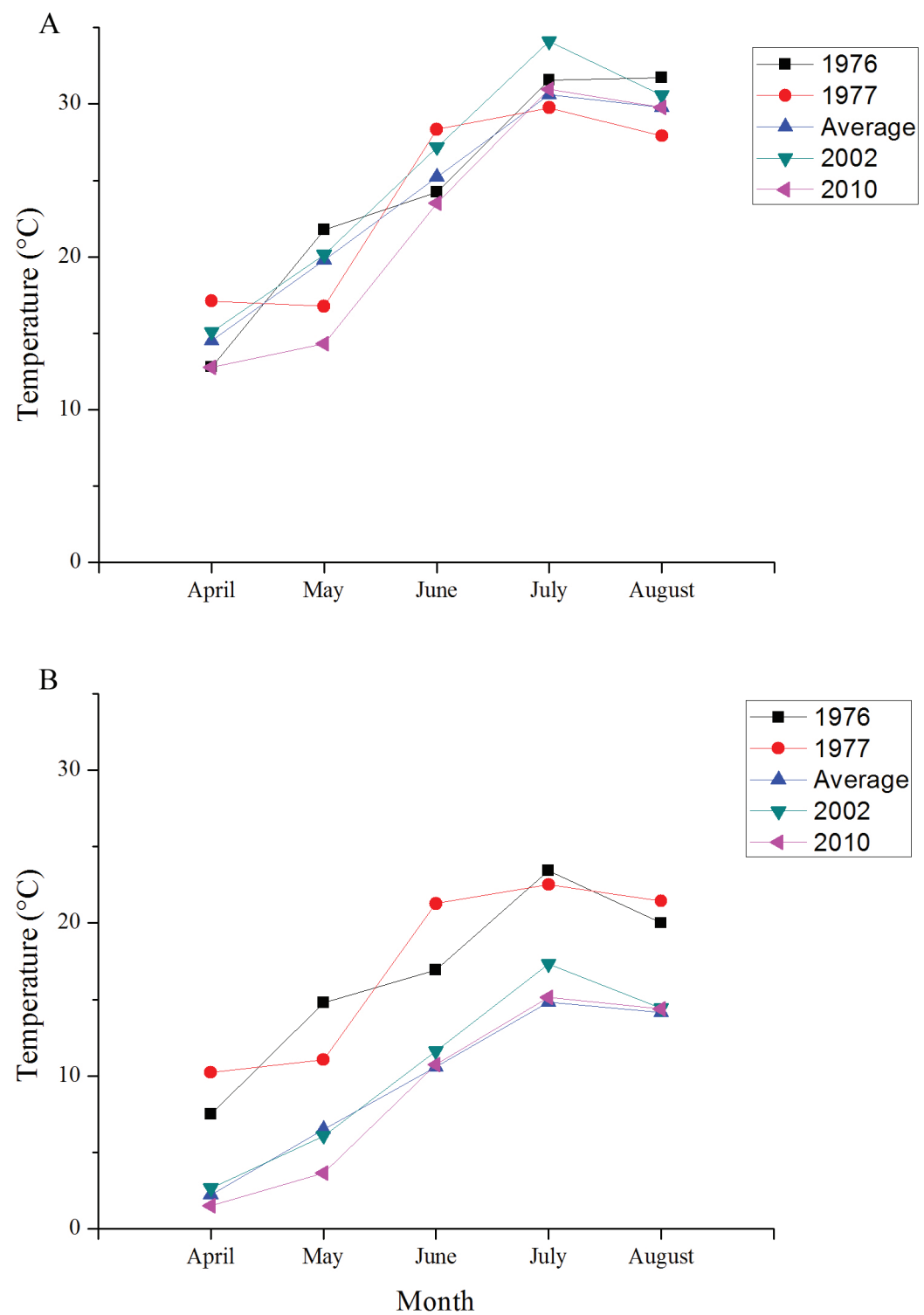

Figure 4. Average daily maximum (a) and minimum (b) temperatures for the four years of study on $H$. farinosus in Green Canyon and the seasonal average over the previous 65 years.

$37,2002: \bar{x}=13.06, S D=13.36, N=81, W=1727.5, p=0.184$ ) (Table 3). Brood per working female (as estimated based on workers present) did differ significantly between years with a greater amount of productivity per female occurring in $2010(2010, \overline{\mathrm{x}}=$ $6.99, \mathrm{SD}=4.21, \mathrm{~N}=35)(2002, \overline{\mathrm{x}}=6.09, \mathrm{SD}=7.11, \mathrm{~N}=70)(\mathrm{W}=914, \mathrm{p}=0.021)$. The percent difference in head width between queens and workers was significantly greater in 2010 than in $2002(8.79 \%$ cf $5.79 \%$; $\mathrm{W}=424, \mathrm{p}=0.027)$. The proportion 


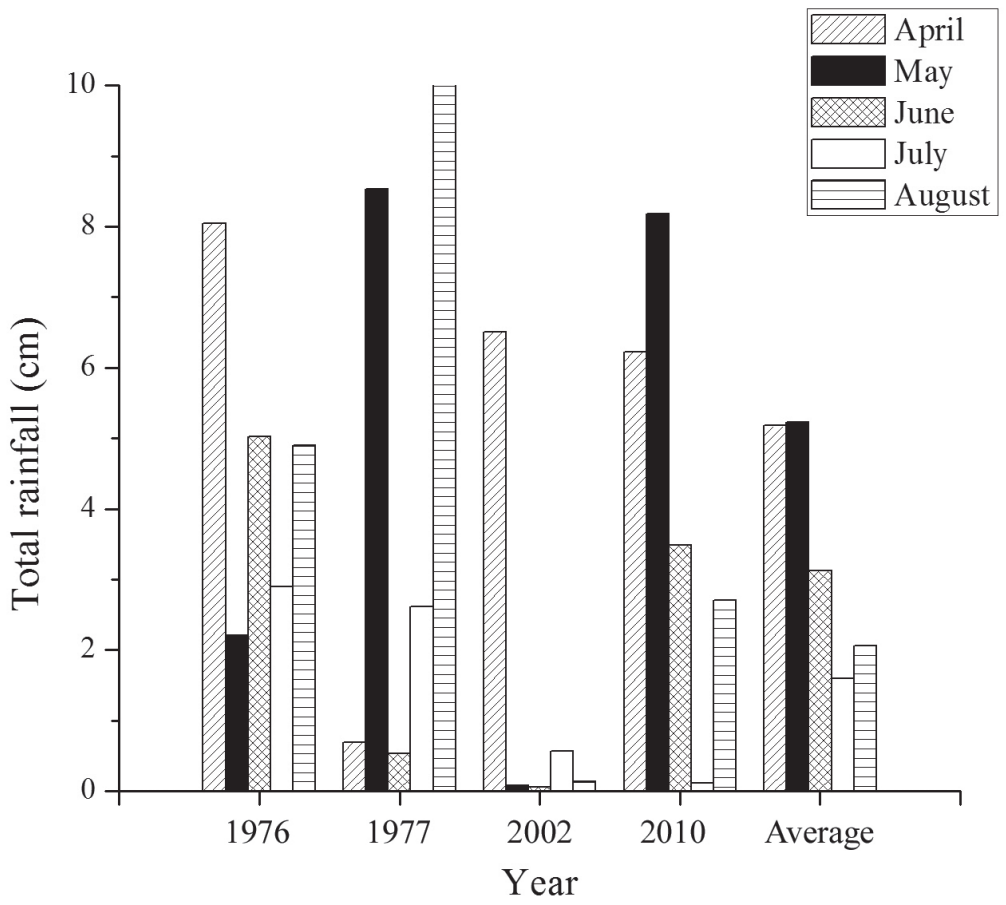

Figure 5. Total rainfall per month for the four years of study on $H$. farinosus in Green Canyon and the monthly average over the previous 65 years.

Table 4. Summary of egg development and matedness in queens and workers in 2002 and 2010. Averages are presented with standard deviations. Females are grouped based on their development score (ds).

\begin{tabular}{c|c|c|c|c|c|c}
\hline & $\mathbf{2 0 0 2}$ & & $\mathbf{2 0 1 0}$ & & & \\
\cline { 2 - 7 } & Queens & Workers & Queens & Workers & $\begin{array}{c}\text { Workers: } \\
\text { Queen present }\end{array}$ & $\begin{array}{c}\text { Workers: Queen } \\
\text { not present }\end{array}$ \\
\hline $\mathrm{N}$ & 46 & 91 & 31 & 49 & 26 & 23 \\
\hline $\begin{array}{c}\text { Number of females } \\
\text { with ds }<0.5\end{array}$ & 4 & 40 & 2 & 21 & 12 & 9 \\
\hline $\begin{array}{c}\text { Number of females } \\
0.5<\mathrm{ds}<1\end{array}$ & 4 & 15 & 9 & 13 & 7 & 6 \\
\hline $\begin{array}{c}\text { Number of females } \\
\text { with ds }>1\end{array}$ & 38 & 36 & 20 & 15 & 7 & 8 \\
\hline $\begin{array}{c}\% \text { with developed } \\
\text { ovaries }\end{array}$ & 93.4 & 60.4 & 96.8 & 73.4 & 73.1 & 69.6 \\
\hline $\begin{array}{c}\text { \% mated } \\
\text { Average amount of } \\
\text { ovarian development }\end{array}$ & $\begin{array}{c}1.429+/- \\
0.765\end{array}$ & $\begin{array}{c}0.913+/- \\
1.070\end{array}$ & $\begin{array}{c}1.185+/- \\
0.668\end{array}$ & $\begin{array}{c}0.648+/- \\
0.673\end{array}$ & $\begin{array}{c}0.625+/- \\
0.458\end{array}$ & $0.793+/-0.842$ \\
\hline
\end{tabular}

of workers that were mated also differed greatly between years with $77.5 \%$ of workers mated in 2010 and only $46.1 \%$ mated in 2002 (Table 4). A greater percentage of workers in 2010 had developed ovaries but the average level of egg development in workers was not significantly different between years $(\mathrm{W}=2114.5, \mathrm{p}=0.607$, Table 4). 

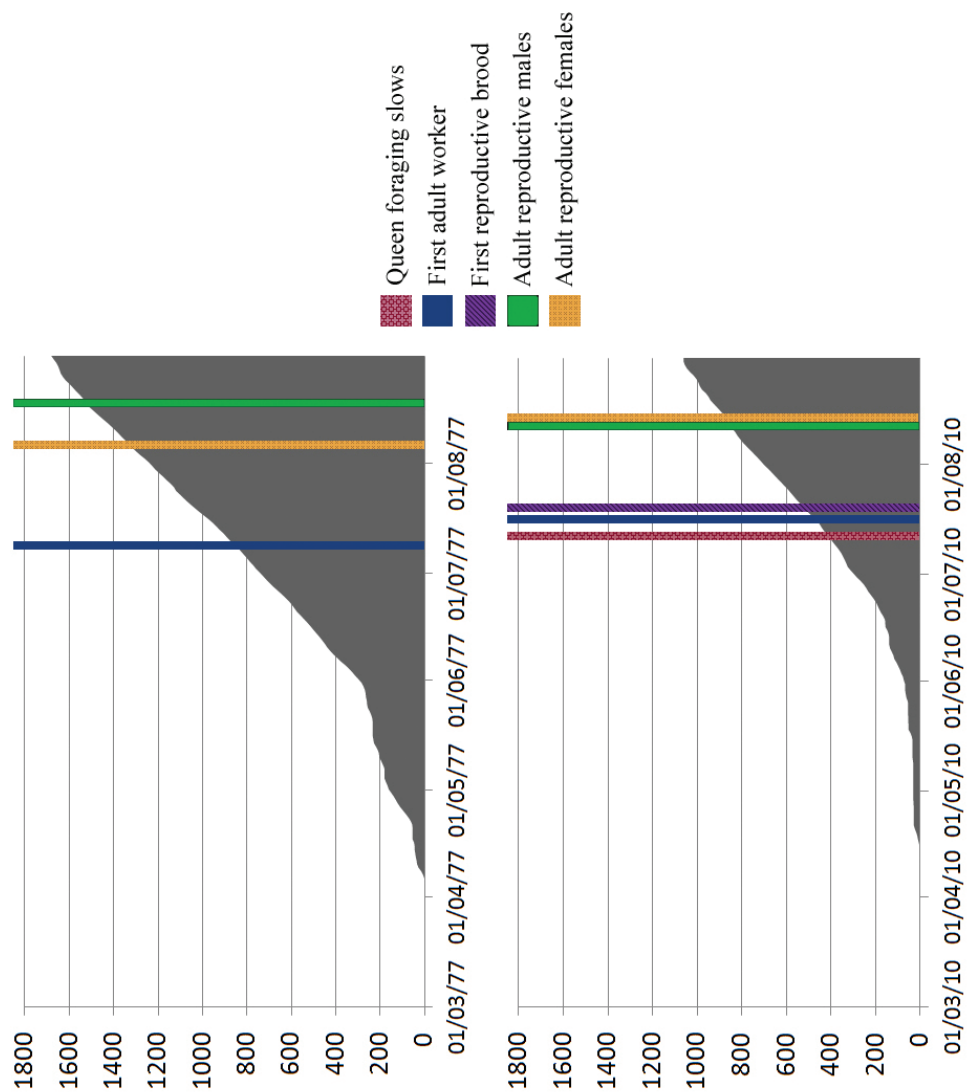

蒂 节 3 盯

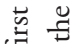

की

范

bo

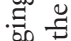

뉸

एँ

艺

๑ $N$

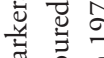

콣 을.

.ี艹

$\stackrel{0}{\stackrel{0}{0}}$

응 웅

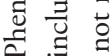

$\dot{0}$ ป

จิ

롤

4 $\sqrt{2}$

유웛

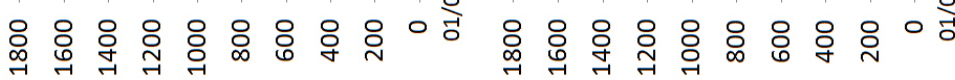

$\infty$ T.

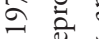

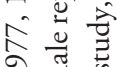
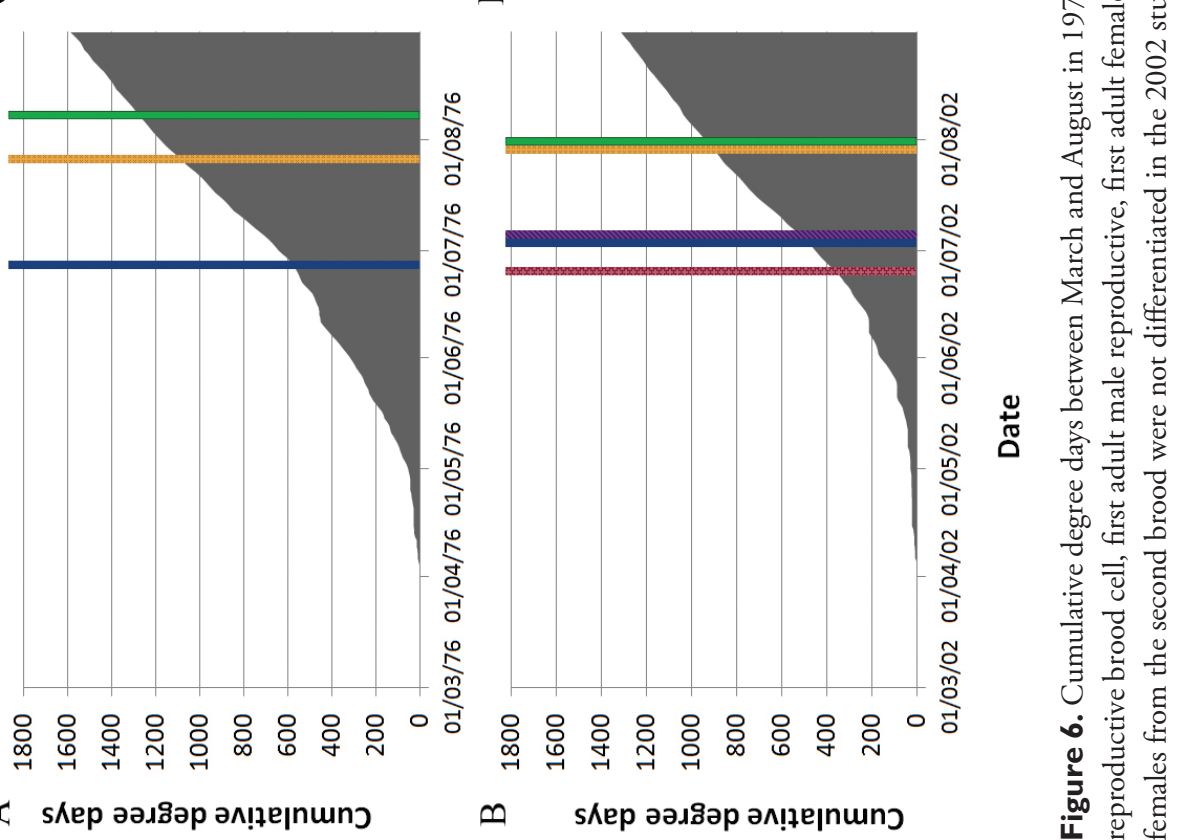

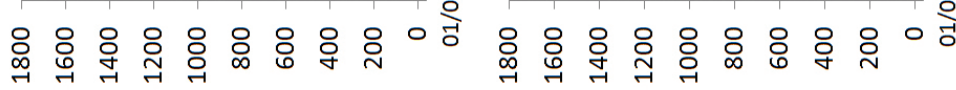




\section{Discussion}

\section{Comparisons of nesting biology of Halictus farinosus among years}

Halictus farinosus was studied at Green Canyon in the 1970s by Nye (1980) and in 2001 and 2002 by Sellars (2004). In this section we compare the results obtained among years.

A combination of temperature and rainfall patterns explain variation in phenological events in $H$. farinosus between 2002 and 2010: major events in the colony cycle coincide well with the number of degree days accumulated, with the first adult brood emerging at around 500 degree days (by equation (2), Figure 6). However, in 1976 and 1977 minimum temperatures were much higher and a larger number of degree days had accumulated before workers emerged ( 800 and 600 days respectively, Figure 6).

The amount of rainfall may have been responsible for the differences in emergence dates between years and the poor correlation with degree day accumulation. Brood development and emergence dates (Table 1) were delayed about two weeks in 2010 compared to 2002 (Sellars 2004) but were similar to those reported by Nye (1980) for 1977. Timing in 1976 was intermediate (Table 1). The amount of spring rainfall followed the same pattern: high in May of 1977 and 2010 low in 2002 and intermediate in 1976. The drier weather in May of 1976 and 2002 likely allowed queens to initiate foraging earlier, to forage more often than in 1977 and 2010 and to produce brood sooner.

Despite the differences in phenology and weather patterns between 2002 and 2010, there were no significant differences in brood size in either brood producing period. More brood were produced per working female in 2010 than in 2002 but this likely reflects differences in the excavation schedule between the two years given that a greater proportion of nests were excavated later in the season in 2010 when more brood and fewer workers were present.

Differences in weather patterns may account for the disparity in caste size dimorphism between years. Weather was much harsher in the spring of 2010 with more rain and colder temperatures compared to 2002 (Figures 4, 5, 6). Poor spring weather conditions may have led to smaller workers being produced in 2010 compared to 2002, as found for a congeneric species by Richards and Packer (1996). It is generally thought that smaller individuals are less effective at foraging than larger ones because they cannot forage as far or carry as much pollen (Gathmann and Tscharntke 2002; Richards 2004). Floral resources in Green Canyon are generally very sparse (Nye 1980; Sellars 2004; personal observations) and foraging trips in the Halictus farinosus population there are typically very long, often well over an hour (Nye 1980; Sellars 2004; personal observations), though it is not known if this is a local phenomenon or if it is typical of the species. Despite this worker size difference, reproductive nest productivity between the two years was not significantly different.

A much greater percentage of workers in 2010 were found to be mated compared to 2002 and ovarian development in workers was comparable between years (Table 
4). This result is unexpected as the workers would be predicted to be less fertile when the queen-worker size differential is larger and queens presumably have more control (Richards et al. 1995; Richards and Packer 1996). A smaller proportion of the first brood in 2002 were male (5.1\%), compared to 2010 (15.9\%) indicating that perhaps fewer males were available to mate with first brood females in 2002. In addition, excavations in 2002 were performed at regular intervals throughout the season as opposed to 2010 where many were excavated in a short period of time late in the season. The difference in excavation dates between years could account for the greater number of mated workers and greater than expected ovarian development in workers in 2010.

\section{Comparisons to other Halictus species}

Phylogenetic data, both morphological (Pesenko 1984) and molecular (Danforth et al. 1999) have been used to understand the systematics of Halictus. Halictus farinosus forms a sibling species pair with $H$. parallelus Say which, although stated by Knerer (1980) to be solitary, is a social species (Packard 1868; Taylor and Packer unpublished observations). These two are closely related to the socially polymorphic $H$. rubicundus Christ (Soucy 2002; Soro et al. 2010) and the solitary, occasionally communal, $H$. quadricinctus Fabricius (Knerer 1980; Sitdikov 1987). It is more distantly related to the other Halictus species that are known to be eusocial such as $H$. ligatus Say and $H$. sexcinctus Fabricius (Packer 1986; Richards 2001), though the latter exhibits some additional social complexities (Richards et al. 2003).

Halictus farinosus produces a small number of workers and has low to moderate worker-queen size dimorphism compared to other social Halictus species (Table 5). It also has a comparatively large number of worker females that are mated and/or have ovarian development, but this varies widely between years. Small size dimorphism, the small number of workers and high degree of mating and ovarian development in workers indicates that the level of sociality in $H$. farinosus is relatively weak compared to that in other social Halictus species (Packer 1992). The nesting biology and behav-

Table 5. Comparison of aspects of sociality and natural history in social species of the subgenus Halictus.

\begin{tabular}{c|c|c|c|c}
\hline & H. farinosus & H. rubicundus & H. ligatus & H. sexcinctus \\
\hline First brood size & $3.5-3.6$ & 4.4 & $5.8->9$ & $7-8.5$ \\
\hline Second brood size & $13.0-13.5$ & 10.5 & $10-16$ & $4.9-5.8$ \\
\hline First brood sex ratio & $5-15 \%$ & $10.3 \%$ & $5.5-14 \%$ & $23 \%$ \\
\hline $\begin{array}{c}\% \text { workers with ovarian } \\
\text { development }\end{array}$ & $60.4-77.4 \%$ & N/A & $57.16 \%$ & $73.70 \%$ \\
\hline$\%$ workers mated & $46.1-77.5 \%$ & N/A & $42 \%$ & $56 \%$ \\
\hline $\begin{array}{c}\text { Queen-worker size } \\
\text { dimorphism }\end{array}$ & $6.4-8.6 \%$ & $9.6 \%$ & $12.7 \%$ & $6.9-11.8 \%$ \\
\hline Source & $\begin{array}{c}\text { Sellars, 2004; } \\
\text { Present study }\end{array}$ & $\begin{array}{c}\text { Soucy, 2002 (social } \\
\text { populations) }\end{array}$ & $\begin{array}{c}\text { Packer, 1986; Richards } \\
\text { and Packer, 1995 }\end{array}$ & $\begin{array}{c}\text { Richards, } \\
2001\end{array}$ \\
\hline
\end{tabular}


ior of social populations of $H$. rubicundus are similar to those of $H$. farinosus in brood size, nest architecture and the level of caste size dimorphism (Table 5; Soucy 2002). However, unlike $H$. farinosus, $H$. rubicundus is socially polymorphic (Eickwort et al. 1996; Soucy and Danforth 2002; Soro et al. 2010). While solitary and social populations of $H$. rubicundus may form phylogenetically separate lineages (Soucy and Danforth 2002) some halictines exhibit social polymorphism even within the same population (Packer 1990; Richards et al. 2003; Hirata and Higashi 2008). While there are no known solitary $H$. farinosus populations, seasonal climatic differences might affect its sociality through the queen-worker size differential (Richards and Packer 1996). The biology of $H$. farinosus should be studied in locations throughout its geographic distribution, including populations at high altitude and latitude where the species is more likely to be solitary, to fully understand the effect of climate conditions on life history and sociality in this species and determine whether solitary behavior is within the species' repertoire.

\section{Acknowledgements}

This work was funded by an NSERC discovery grant awarded to Dr. Laurence Packer and the junior author's salary. We thank Terry Griswold and David Trew for their assistance and advice regarding field methodology. We also thank Cory Sheffield, Jessica Albert and two anonymous reviewers for their helpful comments on the manuscript.

\section{References}

Albert J (2012) Natural history and sociogenetic organization of the bee Halictus farinosus (Hymenoptera: Halictidae) in Northern Utah. Master's Thesis. York University (Toronto, Ontario).

Ascher JS, Pickering J (2011) Bee species guide (Hymenoptera: Halictidae). http://www.discoverlife.org $/ \mathrm{mp} / 20 \mathrm{q}$ ? guide=Halictus

Bartomeus I, Ascher JS, Wagner D, Danforth BN, Colla S, Kombluth S, Winfree R (2011) Climate-associated phenological advances in bee pollinators and bee-pollinated plants. Proceedings of the National Academy of Sciences 108: 20645-20649. doi: 10.1073/ pnas. 1115559108

Cardinal S, Danforth BN (2011) The antiquity and evolutionary history of social behavior in bees. PLOS one 6(6): e21086. doi: 10.1371/journal.pone.0021086

Danforth BN, Sauquet H, Packer L (1999) Phylogeny of the bee genus Halictus (Hymenoptera: Halictidae) based on parsimony and likelihood analyses of nuclear EF- $1 \alpha$ sequence data. Molecular Phylogenetics and Evolution 13: 605-618. doi: 10.1006/mpev.1999.0670

Eickwort GC (1985) The nesting biology of the sweat bee Halictus farinosus in California with notes on H. ligatus (Hymenoptera: Halictidae). Pan-Pacific Entomologist 61: 122-137. 
Eickwort GC, Eickwort, JM, Gordon J, Eickwort MA (1996) Solitary behavior in a high altitude population of the social sweat bee Halictus rubicundus (Hymenoptera: Halictidae). Behavioral Ecology and Sociobiology 38: 227-233. doi: 10.1007/s002650050236

Gathmann A, Tscharntke T (2002) Foraging ranges of solitary bees. Journal of Animal Ecology 71: 757-764. doi: 10.1046/j.1365-2656.2002.00641.x

Hirata M, Higashi S (2008) Degree-day accumulation controlling allopatric and sympatric variations in the sociality of sweat bees, Lasioglossum (Evylaeus) baleicum (Hymenoptera: Halictidae). Behavioral Ecology and Sociobiology 62: 1239-1247. doi: 10.1007/s00265008-0552-1

Knerer G (1980) Biology and social behavior of bees of the genus Halictus (Hymenoptera: Halictidae). Zoologische Jahrbuecher Abteilung fuer Systematik Oekologie und Geographie der Tiere 107: 511-536.

Maynard Smith J, Szathmary E (1995) The Major Transitions of Evolution. Freeman, Oxford.

Minckley RL, Wcislo WT, Yanega D, Buchmann SL (1994) Behavior and phenology of a specialist bee (Dieunomia) and sunflower (Helianthus) pollen availability. Ecology 75: 1406-1419. doi: $10.2307 / 1937464$

Mueller UG (1996) Life history and social evolution of the primitively eusocial bee Augochlorella striata (Hymenoptera: Halictidae). Journal of the Kansas Entomological Society 69: 116-138.

Nye WP (1980) Notes on the biology of Halictus (Halictus) farinosus Smith (Hymenoptera: Halictidae). U S Department of Agriculture Science and Education Administration Agricultural Research Results 11: 1-29.

Ordway E (1965) Caste differentiation in Augochlorella (Hymenoptera, Halictidae). Insectes Sociaux 12: 291-308. doi: 10.1007/BF02222719

Packard AS (1868) The home of the bees (Concluded). The American Naturalist 1: 596-606. doi: $10.1086 / 270153$

Packer L (1986) The social organisation of Halictus ligatus (Hymenoptera; Halictidae) in southern Ontario. Canadian Journal of Zoology 64: 2317-2324. doi: 10.1139/z86-345

Packer L (1990) Solitary and eusocial nests in a population of Augochlorella striata (Provancher) (Hymenoptera: Halictidae) at the northern edge of its range. Behavioral Ecology and Sociobiology 27: 339-344. doi: 10.1139/z86-345

Packer L (1992) The social organization of Lasioglossum (Dialictus) laevissimum in southern Alberta. Canadian Journal of Zoology 70: 1767-1774. doi: 10.1139/z92-244

Packer L, Knerer G (1986) The biology of a sub-tropical population of Halictus ligatus Say I: phenology and social organisation. Behavioral Ecology and Sociobiology 18: 363-375. doi: $10.1007 / \mathrm{BF} 00299667$

Packer L, Owen RE (1994) Relatedness and sex ratio in a primitively eusocial halictine bee. Behavioral Ecology and Sociobiology 34: 1-10. doi: 10.1007/BF00175452

Parker FD (1981) Sunflower pollination: abundance, diversity, and seasonality of bees and their effect on seed yields. Environmental Entomology 10: 1012-1017.

Parker FD (1982) Efficiency of bees in pollinating onion flowers. Journal of the Kansas Entomological Society 55: 171-175. 
Pereboom JJM, Biesmeijer JC (2003) Thermal constraints for stingless bee foragers: the importance of body size and coloration. Oecologia 137: 42-50. doi: 10.1007/s00442-0031324-2

Pesenko YA (1984) A subgeneric classification of bees of the genus Halictus sensu-stricto (Hymenoptera: Halictidae). English translation of Entomologicheskoe Obozrenie 62: 340-357.

Plateaux-Quénu C (1983) Le volume d'un pain d'abeille influence-t-il le sexe de l'oeuf pondu sur lui? Etude expérimental portant sur la premiere couvée d'Evylaeus calceatus (Scop.) (Hym., Halictinae). Annales Des Sciences Naturelles Zoologie 13: 41-52

R Core Team (2012) R: A language and environment for statistical computing. R Foundation for Statistical Computing, Vienna, Austria. URL: http://www.R-project.org/

Richards MH (2001) Nesting biology and social organization of Halictus sexcinctus (Fabricius) in southern Greece. Canadian Journal of Zoology 79: 2210-2219.

Richards MH (2004) Annual and social variation in foraging effort of the obligately eusocial sweat bee, Halictus ligatus (Hymenoptera: Halictidae). Journal of the Kansas Entomological Society 77: 484-502. doi: 10.2317/E37.1

Richards MH, Packer L (1994) Trophic aspects of caste determination in Halictus ligatus, a primitively eusocial sweat bee. Behavioral Ecology and Sociobiology 34: 385-391. doi: 10.1007/BF00167329

Richards MH, Packer L (1995) Annual variation in survival and reproduction of the primitively eusocial sweat bee Halicus ligatus (Hymenoptera: Halictidae). Canadian Journal of Zoology 73: 933-941. doi: 10.1139/z95-109

Richards MH, Packer L (1996) The socioecology of body size variation in the primitively eusocial sweat bee, Halictus ligatus (Hymenoptera: Halictidae). Oikos 77: 68-76. doi: $10.2307 / 3545586$

Richards MH, Packer L, Seger J (1995) Unexpected patterns of parentage and relatedness in a primitively eusocial bee. Nature 373: 239-241. doi: 10.1038/373239a0

Richards MH, von Wettberg EJ, Rutgers AC (2003) A novel social polymorphism in a primitively eusocial bee. Proceedings of the National Academy of Science USA 100: 7175-7180. doi: 10.1073/pnas.1030738100

Richards MH, Vickruck JL, Rehan SM (2010) Colony social organisation of Halictus confusus in Southern Ontario, with comments on Sociality in the Subgenus H. (Seladonia). Journal of Hymenoptera Research 19: 144-158. URL: http://www.brocku.ca/webfm_send/6750

Roulston TH, Cane JH (2002) The effect of pollen protein concentration on body size in the sweat bee Lasioglossum zephyrum (Hymenoptera: Apiformes). Evolutionary Ecology 16: 49-65. doi: 10.1023/A:1016048526475

Schwarz MP, Richards MH, Danforth BN (2007) Changing paradigms in insect social evolution: insights from halictine and allodapine bees. Annual Review of Entomology 52: 127-150. doi: 10.1146/annurev.ento.51.110104.150950

Sellars R (2004) The social organization of Halictus (Halictus) farinosus Smith in northern Utah. Master's Thesis. York University (Toronto, Ontario).

Sitdikov AA (1987) Nesting of the bee Halictus quadricinctus (F.) (Hymenoptera, Halictidae) in the udmurt ASSR. Entomologicheskoye Obozreniye 3: 529-539. 
Soro A, Field J, Bridge C, Cardinal SC, Paxton RJ (2010) Genetic differentiation across the social transition in a socially polymorphic sweat bee, Halictus rubicundus. Molecular Ecology 19: 3351-3363. doi: 10.1111/j.1365-294X.2010.04753.x

Soucy SL (2002) Nesting biology and socially polymorphic behavior of the sweat bee Halictus rubicundus (Hymenoptera: Halictidae). Annals of the Entomological Society of America 95: 57-65.

Soucy S, Danforth BN (2002) Phylogeography of the socially polymorphic sweat bee Halictus rubicundus (Hymenoptera: Halictidae). Evolution 56: 330-341. doi: 10.1603/0013-8746(2002)095[0057:NBASPB]2.0.CO;2

Utah State University climate centre website (2011) http://climate.usurf.usu.edu/products/ data.php.

Zalom FG, Godell PB, Wilson LT, Barnett WW, Bently WJ (1983) Degree days: the calculation and use of heat units in pest management. Division of Agriculture and Natural Resources, University of California, Leaflet 21373. http://cesantabarbara.ucanr.edu/ files/75290.pdf

\section{Appendix}

Table S1: Excavation details for all nests. (doi: 10.3897/JHR.32.4646.app) File format: Adobe PDF file (pdf).

Explanation note: Table listing all excavated nests, the date of excavation and a breakdown of their brood contents by developmental stage.

Copyright notice: This dataset is made available under the Open Database License (http://opendatacommons.org/licenses/odbl/1.0/). The Open Database License $(\mathrm{ODbL})$ is a license agreement intended to allow users to freely share, modify, and use this Dataset while maintaining this same freedom for others, provided that the original source and author(s) are credited.

Citation: Albert JR, Packer L (2013) Nesting biology and phenology of a population of Halictus farinosus Smith (Hymenoptera, Halictidae) in northern Utah. Journal of Hymenoptera Research 32: 55-73. doi: 10.3897/JHR.32.4646. 